\title{
RESEARCHPAPER
}

\section{Estimation of yield and nutrient uptake by onion under the influence of inorganic, organic and bio-fertilizers}

\author{
ABHISHEK SINGH AND R.B. RAM \\ Department of Applied Plant Science (Horticulture), School of Bioscience and Biotechnology, Babasaheb Bhimrao, \\ Ambedkar University (A Central University), VidyaVihar, Raebareli Road, LUCKNOW (U.P) INDIA \\ Email : abhishek0875@gmail.com
}

Article Info :Received : 06.06.2015; Revised : 17.08.2015; Accepted : 03.09.2015

An investigation was carried out to assess the integrated use of inorganic, organic (FYM, pressmud, poultry manure and vermicompost) and bio-fertilizers (Azotobacter, Azospirillum and phosphate solubilizing bacteria) on yield, nutrient uptake byonion and nutrient pool of the soil during Rabi season of the year 2013-14. There was a significant effect of various treatment found on the yield, nutrient uptake and soil nutrient reserve. Maximum yield per hectare were found in 50 per cent recommended $\mathrm{NPK}+50$ per cent vermicompost while minimum yield was observed in control. Maximum uptake of nitrogen and potassium was obtained in treatment combination 50 per cent recommended NPK +50 per cent vermicompost whereas maximum uptake of phosphorus was found in treatment combination 50 per cent recommended NPK +50 per cent pressmud. Among different treatment combination highest nitrogen and potassium reserve in soil was found in treatment combination 50 per cent recommended $\mathrm{NPK}+50$ per cent vermicompost while maximum value for organic carbon percentage was in sole vermicompost application.

Key words : FYM, Pressmud, Vermicompost, Poultry manure, Biofertilisers, Nutrient uptake

How to cite this paper : Singh, Abhishek and Ram, R.B. (2015). Estimation of yield and nutrient uptake by onion under the influence of inorganic, organic and bio-fertilizers. Asian J. Bio. Sci., 10 (2) : 129-132. 